\title{
Review article: bifidobacteria as probiotic agents - physiological effects and clinical benefits
}

\author{
C. PICARD*, J. FIORAMONTI $\dagger$, A. FRANCOIS*, T. ROBINSON*, F. NEANT* \& C. MATUCHANSKY \\ *Danone Vitapole, Centre de Recherche Daniel Carasso, Nutrivaleur, Palaiseau, France; †Neurogastroenterology and \\ Nutrition Unit, INRA, Toulouse, France; †Gastroenterology and Nutritional Support Service, Lariboisière University \\ Hospital, Paris, France
}

Accepted for publication 30 June 2005

\section{SUMMARY}

Bifidobacteria, naturally present in the dominant colonic microbiota, represent up to $25 \%$ of the cultivable faecal bacteria in adults and $80 \%$ in infants. As probiotic agents, bifidobacteria have been studied for their efficacy in the prevention and treatment of a broad spectrum of animal and/or human gastrointestinal disorders, such as colonic transit disorders, intestinal infections, and colonic adenomas and cancer. The aim of this review is to focus on the gastrointestinal effects of bifidobacteria as probiotic agents in animal models and man. The traditional use of bifidobacteria in fermented dairy products and the GRAS ('Generally Recognised As
Safe') status of certain strains attest to their safety. Some strains, especially Bifidobacterium animalis strain DN173010 which has long been used in fermented dairy products, show high gastrointestinal survival capacity and exhibit probiotic properties in the colon. Bifidobacteria are able to prevent or alleviate infectious diarrhoea through their effects on the immune system and resistance to colonization by pathogens. There is some experimental evidence that certain bifidobacteria may actually protect the host from carcinogenic activity of intestinal flora. Bifidobacteria may exert protective intestinal actions through various mechanisms, and represent promising advances in the fields of prophylaxis and therapy.

\section{INTRODUCTION}

The human large intestine is a densely populated microbial ecosystem. Several hundred species of bacteria are usually present and the total weight of microbiota living within the colonic lumen is estimated to be several hundred grams. ${ }^{1}$ There are up to $10^{13}-10^{14}$ total bacteria in the human intestinal tract, i.e. 10- to 20-fold more than the total number of tissue cells in the entire body. ${ }^{2}$ Most of the bacteria are obligate anaerobes, including clostridia, eubacteria, bacteroides groups and the genus bifidobacterium, such as Bifidobacterium bifidum

Correspondence to: Dr C. Picard, Danone Vitapole/Nutrivaleur, RD 128, 91767 Palaiseau Cedex, France.

E-mail: celine.picard@danone.com and Bifidobacterium infantis. Bifidobacterium is a member of the dominant microbiota (i.e. $>10^{8}-10^{9}$ colony forming unit (CFU)/g using culture methods, $>1 \%$ of the total bacteria count using molecular biology methods), both in human faeces $(3.2 \% \pm 0.55$ of total bacterial rRNA) and in the content of the caecal lumen $(5.2 \pm 0.37 \%)$ as shown by culture and molecular hybridization using rRNA-targeted probes or quantitative PCR. ${ }^{3-6}$ Table 1 shows the distribution of bifidobacteria species in the intestinal flora of human adults as evaluated by quantitative PCR.

It is a long-standing belief, which probably originated with Metchnikoff at the turn of the 20th century, that some gut bacteria are beneficial to health, whilst others may be harmful. Obviously, some gut bacteria are harmful in that they produce toxins causing diarrhoea, 
Table 1. Distribution of Bifidobacterium species in the intestinal flora of human adults as evaluated by quantitative PCR. Adapted from Matsuki et al. ${ }^{5} \log _{10}$ bifidobacteria/g of faeces measured by reaction with genus- or species-specific primer*

\begin{tabular}{|c|c|c|c|c|c|c|c|c|}
\hline Species & Genus Bifidobacterium & B. adolescentis & B. angulatum & B. bifidum & B. breve & B. catenulatum & B. longum & B. infantis \\
\hline No. positive (\%) & $46(100)$ & $38(83)$ & $5(11)$ & $13(28)$ & $8(17)$ & $41(89)$ & $44(96)$ & $2(4.3)$ \\
\hline Mean \pm s.d. & $9.4 \pm 0.7$ & $9.1 \pm 0.9$ & $6.6 \pm 0.2$ & $8.3 \pm 0.8$ & $7.3 \pm 0.7$ & $8.9 \pm 0.8$ & $8.1 \pm 0.7$ & $6.9 \pm 0.7$ \\
\hline $\begin{array}{l}\text { Range in positive } \\
\text { subjects }\end{array}$ & {$[6.9 ; 10.6]$} & {$[7.4 ; 10.6]$} & {$[6.3 ; 6.9]$} & {$[6.8 ; 9.4]$} & {$[6.4 ; 8.4]$} & {$[6.3 ; 10.2]$} & {$[6.4 ; 9.4]$} & {$[6.4 ; 7.3]$} \\
\hline
\end{tabular}

* Minimum detection threshold of the method used: $6 \log _{10} \mathrm{CFU} / \mathrm{mL}$.

mucosal invasion and activation of carcinogens is selfevident. Such bacteria are thought to include some Clostridium spp., sulphate-reducing and amino acidfermenting species. The main potentially health-enhancing bacteria are the bifidobacteria and lactobacilli, both of which belong to the lactic acid bacteria (LAB) group. ${ }^{7}$ These two genera do not include any significant pathogenic species and their dominance in the faeces of breast-fed babies is thought to impart protection against infection. ${ }^{8,9}$ The health interest of the Bifidobacterium genus is reflected in the commonly-accepted definition of prebiotics: food ingredients that selectively stimulate the growth and activity of bacteria in the gut, usually bifidobacteria (bifidogenic effect) and lactobacilli thus procuring health benefits. ${ }^{10,11}$

The aim of this review is to focus on the physiological effects of health-promoting bifidobacteria. When considering the study of one specific strain, most of relevant scientific data on Bifidobacteria are focused on Bifidobacterium animalis DN-173 010. For this reason, this species has been used as a reference in this review.

\section{BIFIDOBACTERIA: SAFETY IN USE}

The safe use of bifidobacteria is supported by the long historical consumption of fermented milks and the growing knowledge about bifidobacteria taxonomy and physiology. ${ }^{12,13}$ Lactic acid-producing bacteria in foods are considered as commensal microorganisms with little or no pathogenic potential. ${ }^{14}$ Indeed, a recent review of the safety of lactobacilli and bifidobacteria used as probiotics concluded that they posed no health risks for consumers. $^{15}$

Regarding taxonomy, modern molecular techniques, including polymerase chain reaction-based and other genotyping methods, have become increasingly important for species identification and for the differentiation of bifidobacteria strains. ${ }^{16}$
'16S rRNA sequence analysis (usually used to produce phylogenic trees) is not suitable to distinguish different species of Bifidobacterium. ${ }^{17}$ So, the gene sequence of heat-shock protein of $60 \mathrm{kDa}$ (HSP 60) is preferentially used; furthermore, it is found as a single copy in almost all bacterial species. The phylogenic tree is realized comparing a DNA fragment of $0.6 \mathrm{~kb}$ of the HSP 60 of each studied Bifidobacterium species. The more the sequences are close (in term of percentage of similarities), the more the species are close on the tree'. As an example, Figure 1 presents details about the phylogeny of B. animalis.

It should be noted that this recognition of the safety of such strains will be formalized in a European regulatory framework that is in the process of defining the criteria to be evaluated when assessing the safety of microorganisms used in the food and feed industry. ${ }^{18}$

\section{THE PROBIOTIC CONCEPT}

Probiotics are defined as "live micro-organisms which confer a health benefit on the host when administered in adequate amounts'. ${ }^{19}$ They have been widely tested, in animal and human studies, for their beneficial actions in the prevention or treatment of a broad spectrum of gastrointestinal disorders, from impairment of colonic transit to colonic carcinogenesis. Other functional foods include prebiotics and synbiotics. As already mentioned, prebiotics are defined as a nondigestible food ingredient that beneficially affects the host by selectively stimulating the growth and/or the activity of one or a limited number of bacteria in the colon. $^{20}$ Synbiotics are products in which both a probiotic and a prebiotic are combined.

Some bifidobacteria strains which are used in fermented milks show high survival in the gastrointestinal tract and exhibit probiotic properties in the colon, thus fulfilling therefore criteria for probiotics. ${ }^{21-23}$ 
Figure 1. Bifidobacteria phylogenic tree based on partial HSP60 DNA sequences. Bar, 5\% sequence divergence. Adapted from Jian et al. ${ }^{119}$

\section{Bifidobacteria: survival in the gastrointestinal tract}

Several studies have addressed quantification of probiotic survival during gastrointestinal transit. ${ }^{24}$ Studies using B. animalis DN-173010 demonstrated the high survival of this strain in the small and large intestines when it is ingested in a fermented dairy product. The results of the main studies carried out to assess strain survival are summarized in Table 2.

In a randomized cross-over study, 12 healthy adults were fed $375 \mathrm{~g}$ (125 g, three times a day) of fermented milk containing at least $3.8 \times 10^{9} \mathrm{CFU}\left(2 \times 10^{7} \mathrm{CFU} / \mathrm{g}\right.$ equivalent to $7.5 \times 10^{9} \mathrm{CFU}$ ) of $B$. animalis $\mathrm{DN}-173$ 010. More than $10^{8} \mathrm{CFU} / \mathrm{g}$ were found in the stools, reflecting the strong survival of that strain during its gastrointestinal transit. ${ }^{25}$ Strain survival under
$5 \%$

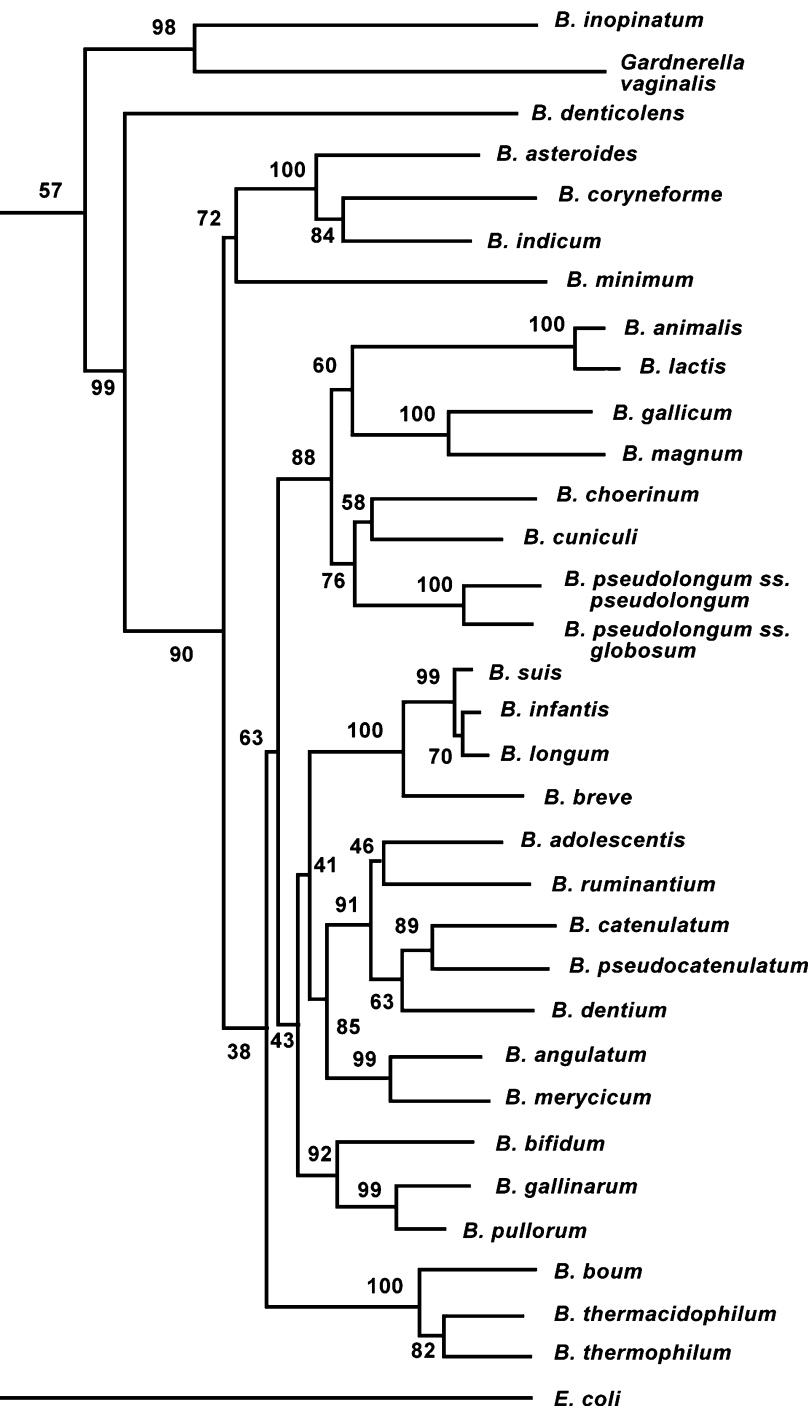

exposure to the gastric environment has been shown to be strain-specific both in vitro and in vivo. ${ }^{23}$ In vitro, B. animalis DN-173 010 and another commerciallyavailable strain, contained in two different fermented dairy products, behaved, indeed, very differently when exposed to a simulated gastric environment; B. animalis DN-173 010 survived very well for at least $90 \mathrm{~min}$ $\left(>10^{7} \mathrm{CFU} / \mathrm{g}\right)$, while the other commercial strain was much less resistant $\left(6 \times 10^{5} \mathrm{CFU} / \mathrm{g}\right){ }^{23} \mathrm{In}$ an in vivo study in man, in which gastric fluid specimens were obtained by intubation, the same authors confirmed that the postgastric survival rate of B. animalis DN-173 010 was high $(80 \%) .^{23}$

As shown in healthy adults, using intestinal tubing reaching the ileum, $23.5 \pm 10.4 \%$ of orally administered B. animalis $\mathrm{DN}-173010$ survived during passage 


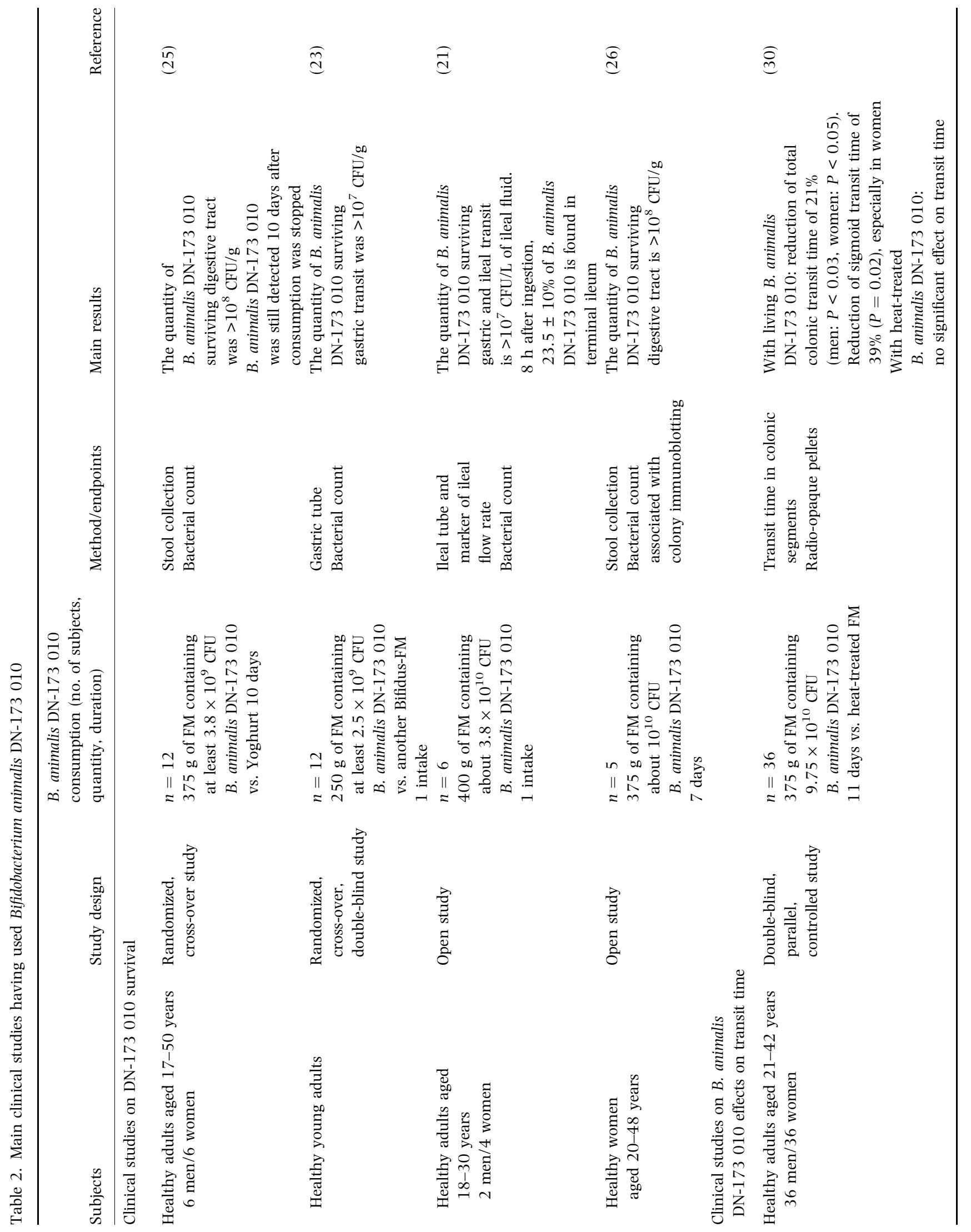




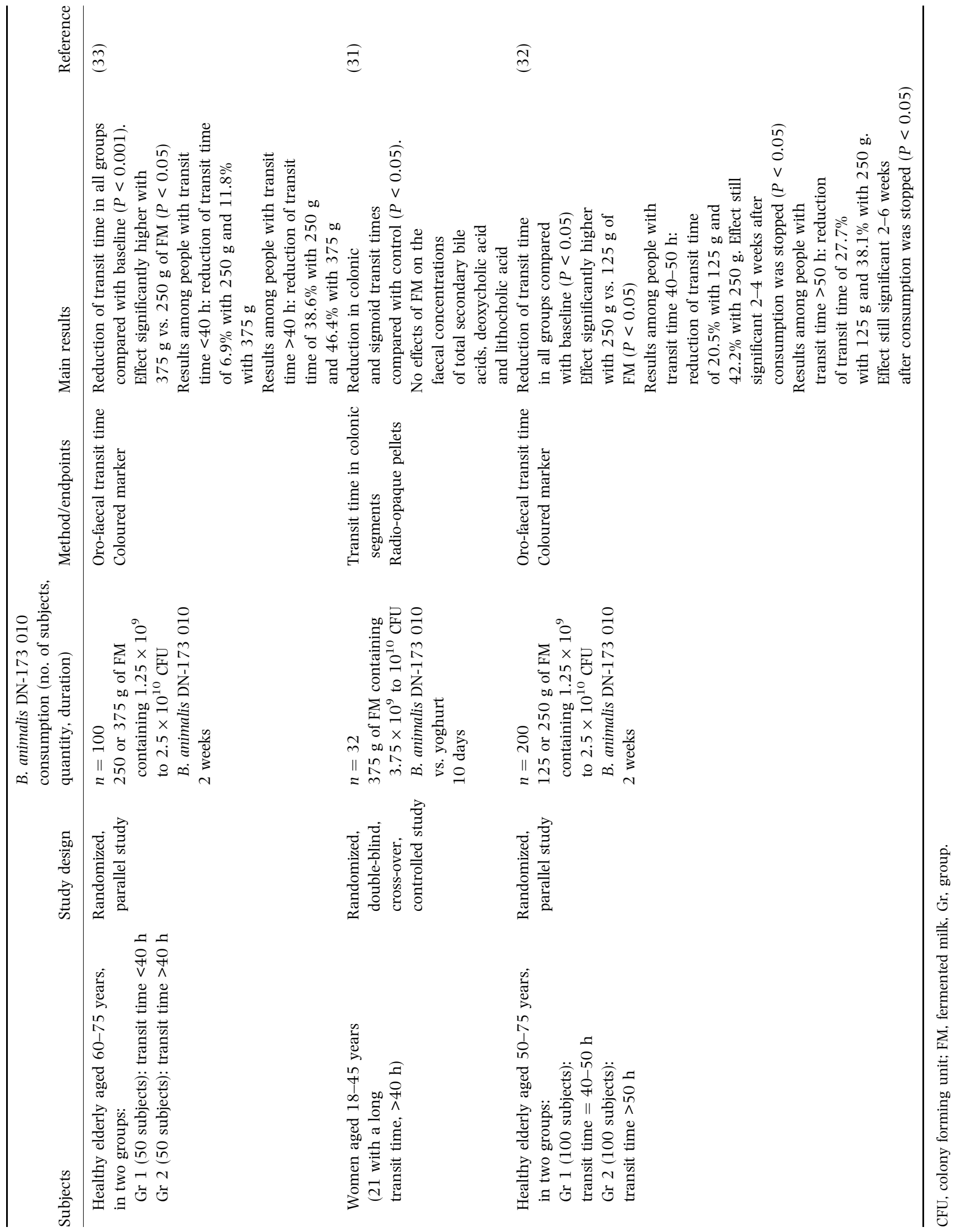


through the stomach and small intestine. The strain was recovered at a flow of $10^{8.8} \mathrm{CFU} / \mathrm{h} .{ }^{26}$ Figure 2 shows the survival of bifidobacteria in simulated gastric environment at various $\mathrm{pH}$. More recently, the digestive survival of B. animalis DN-173 010 was confirmed in five women aged 20-48 years who consumed $375 \mathrm{~g}$ per day of fermented milk for 7 days. ${ }^{27}$

Similar results were reported in studies using other Bifidobacterium species. ${ }^{22,} 28$ In a study involving eight healthy volunteers, the faecal recovery rate for a variant of Bifidobacterium sp. (B. bifidum) that could be distinguished from indigenous bacteria was $29.7 \pm 6.0 \%$ of the ingested dose. When administration of this strain was discontinued, the strain was no longer recovered from the faeces, indicating that Bifidobacterium sp. survives in, but does not colonize, the human colon. ${ }^{22}$ Similarly, Kullen et al. ${ }^{28}$ fed a single commerciallyavailable Bifidobacterium strain to human volunteers and investigated the faecal bifidobacteria flora using a molecular method. As long as feeding continued, total bifidobacteria (including the administered strain) excretion increased, but the test strain disappeared from the faeces after feeding discontinuation.

These studies clearly show that several bifidobacteria strains, including $B$. animalis $\mathrm{DN}-173$ 010, survive

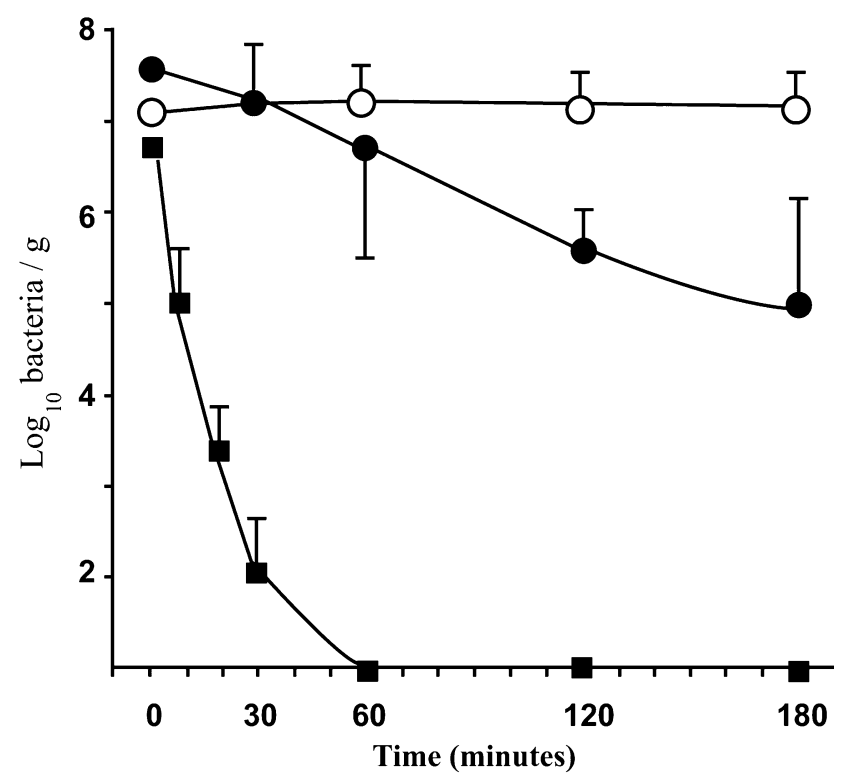

Figure 2. Survival of bifidobacteria after incubation at $\mathrm{pH}$ values of 1 (rectangles), 2 (closed circles) or 3 (open circles), as determined by counts of viable bacteria. Mean \pm s.d.; $n=5$ assays. Adapted from Pochart et al. ${ }^{21}$ gastrointestinal transit without colonizing the gut. Large numbers reach the colon. The high survival rate enables the bacteria to exert physiological effects of potential benefit to the host.

\section{PHYSIOLOGICAL EFFECTS AND CLINICAL BENEFITS OF BIFIDOBACTERIA}

The results of the main human and animal studies carried out to further elucidate the physiological effects of B. animalis strain DN-173 010 and to assess their clinical pertinence are summarized in Tables 2 and 3.

\section{Transit time}

Disturbances of colonic transit, associated with diarrhoea and constipation, are frequent and constitute an important target for functional food, including probiotics. $^{7}$ Several bacterial strains have demonstrated activity against diarrhoea of various aetiologies. ${ }^{29}$

However, several studies have evidenced that probiotics accelerate transit time. In a parallel double-blind study including 70 healthy volunteers, the ingestion $375 \mathrm{~g} /$ day (125 g, three times a day) of milk fermented by B. animalis strain DN-173 010 for 11 days shortened the total colonic transit time by about $20 \%$ vs. the baseline colonic transit time and that of placebo group. The effect was more pronounced in women, particularly in those with a long baseline transit time. ${ }^{30}$ These beneficial effects were not found with heat-treated probiotics products, suggesting that both probiotic survival and metabolic activity are necessary. ${ }^{30}$

Another double-blind, randomized, controlled study has shown that healthy women had shorter $(P<0.05)$ total colonic and sigmoid transit times following ingestion of $375 \mathrm{~g} /$ day of a fermented milk containing yoghurt cultures plus B. animalis DN-173 010 for 10 days compared with the time for the B. animalis strain-free product. ${ }^{31}$ Ingestion of $375 \mathrm{~g}$ of product corresponds to ingestion of $3.6 \times 10^{10}$ CFU of B. animalis DN-173 010 which is of the same order of magnitude on the logarithmic scale than the quantity brought by 125 or $250 \mathrm{~g}$ of product $\left(1.2 \times 10^{10}\right.$, $2.4 \times 10^{10} \mathrm{CFU}$ respectively). While faecal weight, bacterial mass and faecal excretion of secondary bile salts were not significantly influenced, faecal primary bile acid concentrations tended to increase after consumption of the Bifidobacterium-fermented milk, an 


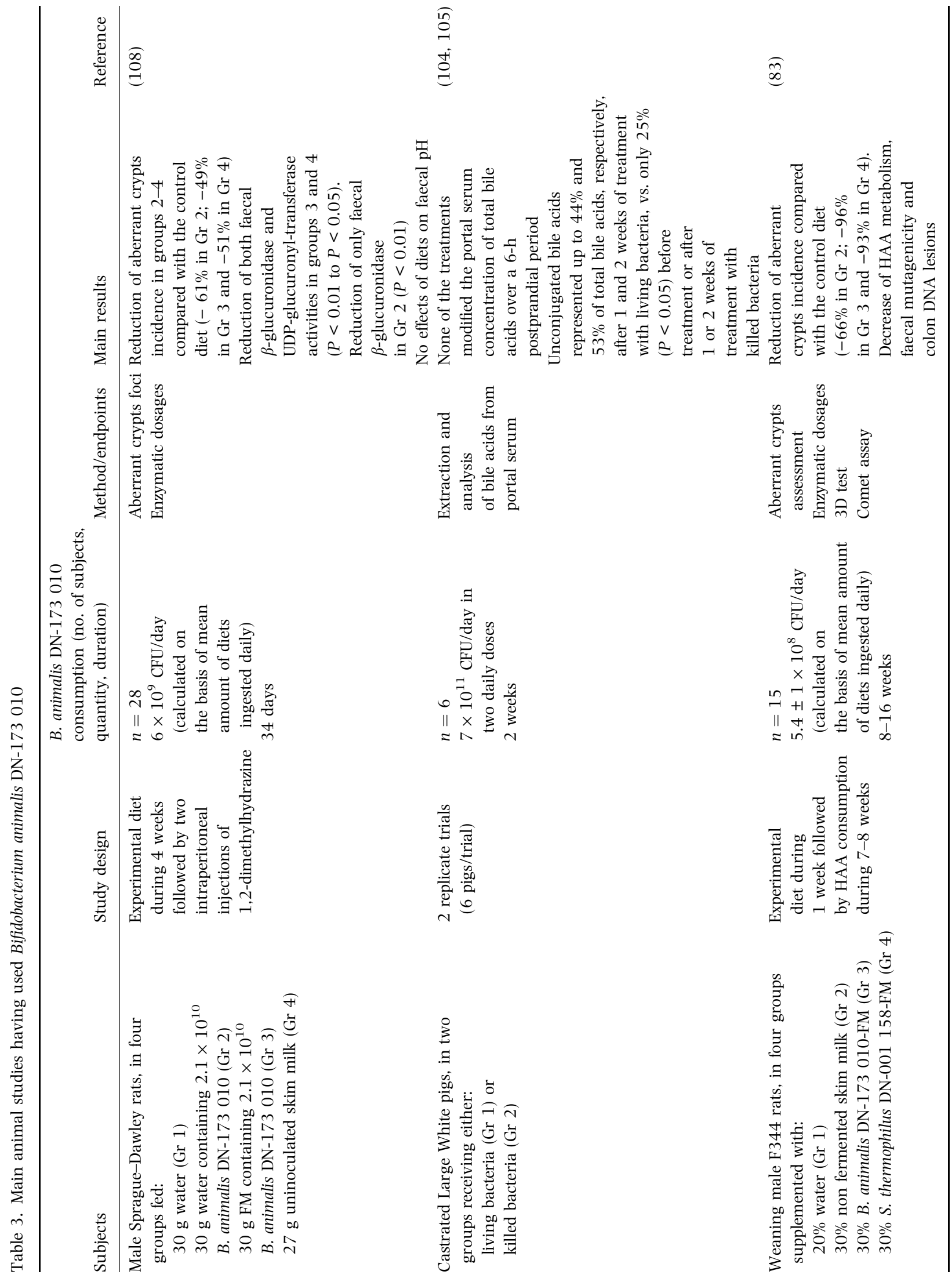


effect which could simply be due to the shorter colonic transit time. ${ }^{32}$

Two studies further investigated the efficacy of different doses of B. animalis DN-173 010-containing fermented milk on transit time, by focusing on elderly subjects. ${ }^{33,} 34$ The first showed that regular consumption of 250 or $375 \mathrm{~g} /$ day of Bifidobacterium fermented milk significantly shortened the gut transit time $(P<0.001)$. The effect was more marked with $375 \mathrm{~g} /$ day than $250 \mathrm{~g} /$ day $(P<0.05) .{ }^{35}$ A second large-scale and open controlled study evaluated lower doses and the duration of the beneficial effects after consumption of the product has been discontinued. The study included 200 elderly volunteers, aged 50-75 years, divided into two groups -100 with normal transit time $(40-50 \mathrm{~h})$ and 100 with a slow transit time $(>50 \mathrm{~h})-$ who were randomized to receive either 125 or $250 \mathrm{~g}$ of Bifidobacterium-fermented milk daily for 2 weeks. ${ }^{33}$ These authors concluded that: (i) in volunteers receiving 125 and $250 \mathrm{~g} /$ day Bifidobacterium-fermented milk, both dosages significantly reduced oro-faecal transit time. These results are shown in Figure 3. The reduction were 20 and $42 \%$ in the group with normal transit time and 28 and $38 \%$ in the group with as slow baseline transit time, respectively; and (ii) the effect upon oro-faecal transit time lasted from 2 to 4 weeks after Bifidobacterium-fermented milk cessation. These results are shown in Figure 3.

Finally, the data show that milk fermented with probiotic Bifidobacterium reduces transit time with a dose-effect response, especially in subjects with slow transit time.

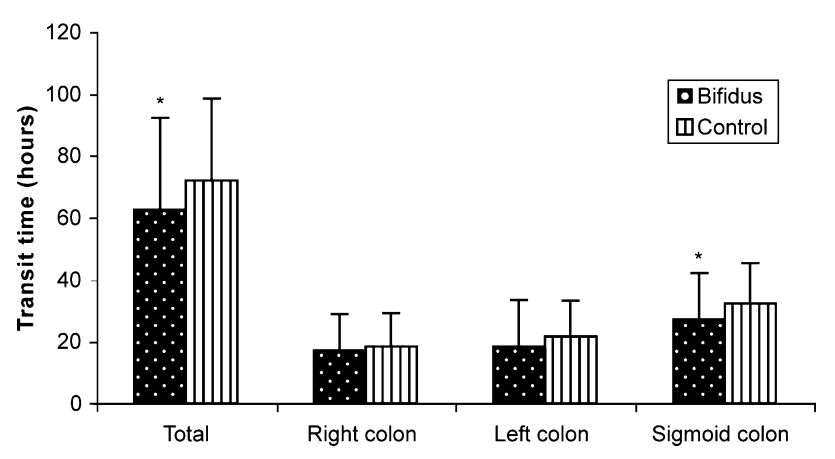

Figure 3. Total and segmental colonic transit time (CTT) at the run-in period and after a 10-day consumption of Bifidobacterium animalis DN-173 010-fermented milk. ${ }^{*} P<0.05$. Adapted from Marteau et al. ${ }^{31}$ 


\section{Colonic fermentation}

Through fermentation, bacterial growth is stimulated (biomass), and organic acids (lactic acid and short chain fatty acids-SCFAs), are produced together with gases: $\mathrm{H}_{2}, \mathrm{CO}_{2}$ and $\mathrm{CH}_{4}$. Lactic acid is produced by many gut bacterial species, mainly bifidobacteria and lactobacilli. SCFAs (mainly acetate, propionate and butyrate) are the major end-products of bacterial fermentative reactions in the colon and the principal anions in the human hindgut. ${ }^{34}$ All SCFAs are rapidly absorbed from the hindgut and stimulate salt and water absorption. They are then metabolized, principally by the gut epithelium, liver and muscle. One of their major properties is their trophic effect on the intestinal epithelium. Moreover, butyrate, a most interesting SCFA, is an important energy source for the colonic epithelium and regulates cell growth and differentiation. ${ }^{35-37}$ Even if bifidobacteria do not produce butyrate directly, they produce lactate that may be transformed in butyrate. ${ }^{38}$ Butyrate has been shown to reduce the rate of transformed cell growth, in a concentration-dependent manner, and to promote expression of differentiation markers in vitro, thus leading to cells reversion from a neoplastic to a non-neoplastic phenotype. ${ }^{37}$

In addition to fermentation products, gut bacteria, including bifidobacteria are able to synthesize vitamins, especially B vitamins. ${ }^{39,}{ }^{40}$ No in vivo data concerning the production of $\mathrm{B}$ vitamins by bifidobacteria and its impact on B vitamins status in humans is available at the present time.

\section{Barrier effects}

A number of mechanisms by which probiotics may protect the host from potentially harmful entities have been proposed, e.g. production of inhibitory substances, blockade of adhesion sites and stimulation of immunity. ${ }^{41}$

\section{Production of inhibitory substances. Bifidobacterium infan-} tis strain has been shown to exert a broad spectrum of antimicrobial properties through production of antimicrobial compounds, unrelated to acid production, which inhibit the growth of pathogens. ${ }^{42}$ In other studies, the activity of bifidobacteria strains in vitro was shown to result from antimicrobial compounds present in the spent culture supernatants, suggesting that the compounds were secreted. ${ }^{41}$ Interestingly, Fujiwara et al. ${ }^{43}$ recently described a protein factor produced by Bifido- bacterium longum SBT 2928, with a molecular weight of at least 100 000, which inhibited adhesion of enterotoxigenic Escherichia coli strain $\mathrm{Pb} 176$ which expresses colonization factor adhesion II, to the gangliotetrasylceramide GA1 molecule in vitro. Two strains of bifidobacteria were found to produce an antibacterial lipophilic factor (or several factors) with an estimated molecular weight of $<3500 .{ }^{41}$

Blockade of adhesion sites. Probiotics may prevent infection by out-competing with pathogenic viruses or bacteria for binding sites on epithelial cells. ${ }^{44-46}$ In a study using human Caco-2 cell cultures, B. animalis DN173010 demonstrated adhesion properties to human cells, even when EGTA was added to the medium: this confirms that adhesion of this Bifidobacterium strain to intestinal cells is not calcium-dependent. Further investigation on this strain showed that no extra cellular protein factor is required for its adhesion (A. Servin, personal communication).

Stimulation of immunity. In experimental conditions, $B$. longum increases the immunological and defensive functions of germ free mice. ${ }^{4-49}$ Bifidobacterium breve YIT4064 enhances antigen specific IgA-antibody directed against rotavirus in the mouse. ${ }^{50}$

The barrier effect generated by some probiotics may derive from positive modulation of the mucous layer that separates the intestinal lumen from the colonocytes. Indeed, probiotics may change the gut mucosal barrier by stabilizing the intestinal mucosa, normalizing intestinal permeability and improving gut immunology, leading to the prevention of the overgrowth of pathogenic bacteria and viruses. ${ }^{50,51}$

Much work remains to be done to specify the mechanisms of action of particular probiotics against particular pathogens and to show the translation of these mechanisms into human benefits.

\section{Effects on colonic immune system}

The first contact that ingested bacteria have with the immune system is the gut-associated lymphoid tissue (GALT) ${ }^{52}$ The human intestine is the largest mass of lymphoid tissue in the body, containing over $10^{6}$ lymphocytes/g of tissue. Different components of the mucosal immune system act to focus a specific response against exogenous antigens. The first line in this defence is the secretory IgA system, ${ }^{52}$ which produces abundant 
mucosal antibodies. The main function of secretory antibodies, in cooperation with non-immunological defence mechanisms, is to mediate exclusion of foreign antigens by preventing epithelial adherence and penetration of invasive pathogenic microorganisms. The antibodies are also responsible for neutralizing toxins and viral multiplication. ${ }^{53}$

The dual role of the digestive flora with respect to the immune is noteworthy. Bacteria (pathogenic or nonpathogenic) constitute antigens that elicit specific systemic and local immune responses. Furthermore, they exert a considerable influence on the number and distribution of the GALT cell populations and play an important role in the regulation of immune responses. ${ }^{54}$ These findings mainly derive from animal studies using germ-free and gnotobiotic animal models. Direct evidence in humans is scarce and only hypotheses can be extrapolated from experimental results mainly obtained in mice. In any event, the cellular and molecular events through which the digestive flora modulates the immune system are still poorly understood. ${ }^{52}$

Several probiotics have been reported to stimulate the immune system through non-specific modes of action, resulting in increased immune responsiveness to a wide variety of antigens. In most studies, markers of immune response, rather than disease symptoms, were studied in order to elucidate the mechanisms involved. ${ }^{55}$ In uncontrolled studies, B. bifidum Bb12 $\left(1 \times 10^{10} \mathrm{CFU} /\right.$ day) and Lactobacillus acidophilus La1 $\left(7 \times 10^{10} \mathrm{CFU} /\right.$ day), each given to 14 volunteers for 3 weeks, doubled the number of peripheral white blood cells with phagocytic activity from baseline to the end of the follow-up. ${ }^{56,57}$ In a controlled study, B. bifidum and L. acidophilus $\left(8 \times 10^{6} \mathrm{CFU} /\right.$ day of each for 28 days $)$ were shown to reduce colonic inflammatory infiltration in 15 elderly subjects. ${ }^{58}$ These subjects were 25 institutionalized patients aged $>70$ years with no overt diseases, according to anamnesis and absence of symptoms such as fever, pain, cough, dysuria and modification of bowel habits. All subjects underwent colonoscopy and multiple endoscopic biopsies, in addition to measurement of blood parameters. The probiotic group showed reduced $(P<0.02)$ total number of T, B and Leu 7 lymphocytes per field in the sigmoid and descending colon; peripheral B lymphocytes increased significantly. No colonic or blood changes were seen in the placebo (sucrose and gelatine) group. ${ }^{58}$ Further studies using non-enriched fermented milk as a placebo need to be conducted. ${ }^{59}$
Enhancement of the non-specific immune phagocytic activity of granulocyte populations in the blood of human volunteers has been reported following consumption of L. acidophilus and Bifidobacterium sp. ${ }^{56}$ As phagocytic activity contributes to natural immunity and phagocytes are involved in antibody immune responses as antigen-presenting cells, the stimulation of intestinal IgA antibody responses induced by tested bacteria may be partly explained by an effect on phagocytic cell functions. Using ELISA and ELISPOT methods, Moreau et al. evaluated the immunostimulating properties in mice of B. animalis DN-173 010 in fermented milk by measuring the intestinal IgA antirotavirus antibody responses, both in the faeces and in small intestine lamina propria cells. Adult gnotobiotic mice harbouring only the $B$. animalis DN-173 010 strain in the gut were infected with a heterologous simian rotavirus strain (SA-11) and the intestinal IgA antirotavirus response compared with that of germ-free mice. ${ }^{60,} 61$ The results provided evidence on the adjuvant effect of $B$. animalis DN-173 010 strain on the enhancement of the intestinal anti-rotavirus $\operatorname{IgA}$ antibody response at both the cellular and faecal levels. $^{60,61}$

These data are in line with studies reporting positive effects of probiotics on various gastrointestinal diseases including infant diarrhoea caused by rotavirus infection.

\section{Effects of bifidobacteria on gastrointestinal disease}

Infectious diarrhoea. Acute infections of the gut are usually self-limiting and characterized by diarrhoea and, often, vomiting. The principal pathogens are viruses and bacteria. Considering the absence or small number of studies specifically relating to bifidobacteria alone in this section, clinical trials involving mixed preparation of probiotics have been introduced.

\section{Diarrhoea because of rotavirus infection}

Rotavirus is the most common cause of acute childhood diarrhoea.

Many clinical studies evaluated the effect of probiotics on rotavirus-associated acute diarrhoea, especially in children. Saavedra et al. conducted a double-blind, placebo-controlled trial. Fifty-five hospitalized infants who were randomized to receive a standard infant formula or the same formula supplemented with 
B. bifidum (later renamed B. lactis) and Streptococcus thermophilus. ${ }^{62}$ During the 17 months of follow up, 31\% of the patients given the standard infant formula, but only $7 \%$ of those receiving the probiotic supplemented formula developed diarrhoea. The prevalence of rotavirus shedding was significantly lower in the infants receiving the probiotic supplemented formula. ${ }^{62}$ This effect was confirmed in a prospective study including 175 children. The study showed that those receiving bifidobacteria-supplemented milk-based formula were protected against symptomatic rotavirus infection. ${ }^{63}$ The prophylactic effect were recently confirmed in a multi-centre, double-blind, controlled trial involving 90 infants aged $<8$ months who lived in residential nurseries or foster care centres. The study evaluated the efficacy of a milk formula supplemented with viable B. lactis strain $\mathrm{Bb} 12$ in terms of the prevention of acute diarrhoea. The number of days with diarrhoea and the daily probability of diarrhoea were significantly reduced in the probiotic group (1.15 \pm 2.5 and 0.84 days $)$ vs. the conventional formula group $(2.3 \pm 4.5$ and 1.55 days). ${ }^{64}$ Feeding infants with $B$. lactis reduced their risk of contracting diarrhoea 1.9-fold (range, $1.33-2.6) .{ }^{65}$

Antibiotic-associated diarrhoea. Diarrhoea caused by the growth of pathogenic bacteria is the most common side effect of antibiotic use. Probiotics may inhibit this growth by releasing inhibitory substances or bacteriocins, as has been demonstrated with some strains in vitro. ${ }^{59,66,67}$ To date, the main probiotics used are Lactobacillus GG, Enterococcus SF68 and Saccharomyces boulardii. ${ }^{68}$ One double-blind placebo-controlled study of 10 adults tested the effects of a daily consumption of 3 cups/day of B. longum yoghurts on erythromycinassociated gastrointestinal effects. ${ }^{69}$ Faecal weight, stool frequency, and abdominal complaints were significantly increased when erythromycin was given with placebo yoghurt but not when $B$. longum yoghurts were being taken. Moreover the simultaneous intake of B. longum yoghurts with erythromycin induced a sharp fall in clostridia spore count, suggesting that these yoghurts could reduce antibiotic-associated alterations in the intestinal microflora. In another study, subjects receiving a mix of prebiotics (fructooligosaccharides) and probiotics (including B. longum BB 536) during oral administration of cefpodoxime proxetil twice daily were shown to be less susceptible to Clostridium difficile colonization than subjects receiving prebiotics only or placebo. ${ }^{69}$ These results were confirmed in a recent double-blind, placebo-controlled study investigating the role of a probiotic containing both Lactobacillus and Bifidobacterium in the prevention of $C$. difficile-associated diarrhoea. The study was conducted on 150 elderly patients receiving antibiotic therapy and randomized to receive the treatment for 20 days. For the patients developing diarrhoea, the incidence of samples positive for $C$. difficile-associated toxins was $2.9 \%$ in the probiotic group vs. $7.25 \%$ in the placebo-control group. When specimens from all patients were tested, $46 \%$ of probiotic patients were $C$. difficile toxin-positive vs. $78 \%$ in the placebo group. ${ }^{70}$

Pouchitis and human inflammatory bowel disease. Acute or chronic inflammation occurs in up to $50 \%$ of ulcerative colitis (UC) patients following proctocolectomy and pouch reconstruction associated with ileoanal anastomosis. ${ }^{71}$ Available data on probiotics and pouchitis are obtained with mixed strains mostly Lactobacillus and bifidobacteria. Much work remains be done to investigate the role for bifidobacteria in this disease.

The most convincing evidence of the clinical effect of probiotics in human inflammatory bowel diseases ${ }^{72}$ was generated by a small prospective, double-blind, placebo-controlled trial showing that a combination of eight probiotic bacteria including three strains of bifidobacteria (longum, breve and infantis) prevented relapse of chronic pouchitis after induction of remission by antibiotics. ${ }^{73}$ These results have been replicated $^{74}$ and partly extended by probiotic administration immediately after ileostomy closure. ${ }^{75}$ Similar favourable clinical results of a mixture of lactobacilli (La-5) and bifidobacteria (Bb-12) on symptoms and endoscopic inflammation in UC patients with pouchitis have been reported. ${ }^{76}$ Other evidence, came from two studies from Ishikawa et al. ${ }^{77}$ and Kato et al. ${ }^{78}$ showing the effectiveness of supplementation with bifidobacteria-fermented milk containing live bifidobacteria (breve and bifidum) and $L$. acidophilus YIT 0168) in the treatment of UC. Both studies were randomized controlled trials - one being placebocontrolled $^{78}$ - but one deals with mild to moderate, active $\mathrm{UC}{ }^{78}$ and the other with the maintenance of remission in UC. ${ }^{77}$ In a recent randomized controlled pilot trial, the short-term synbiotic treatment of active UC was shown to improve the full clinical appearance of chronic inflammation in patients receiving this therapy. ${ }^{79}$ The precise role of each probiotic species, 
including bifidobacteria, and prebiotic substances in these results remains to be determined.

Irritable bowel syndrome. While most, if not all, of 12 clinical trials of probiotics in irritable bowel syndrome (IBS) have concerned lactobacilli (mainly L. plantarum and Lactobacillus GG) and mixtures of lactobacilli and bifidobacteria strains, ${ }^{80}$ superiority for bifidobacterium (B. infantis 35624) over both a lactobacillus (L. salivarius UCC4331) and placebo for alleviating each of the cardinal symptoms of IBS (except for bowel movement frequency and consistency) and for a composite score has been very recently shown. ${ }^{81}$

Colonic tumours. Among environmental factors, genotoxic chemicals ingested in diet may be involved in the development of colorectal cancer, a significant cause of mortality in Western industrialized countries. ${ }^{82}$ Some chemicals are thought to induce the initiation step of the carcinogenetic process, while the majority of them are involved in the promotion step. ${ }^{83}$

\section{Bifidobacteria, bacterial metabolism and colonic} carcinogenesis

Evidence is accumulating that the normal intestinal flora can influence carcinogenesis by producing enzymes that transform procarcinogens into active carcinogens. These enzymes include $\beta$-glucuronidase, azoreductase and nitroreductase. ${ }^{84-88}$

Bacterial $\beta$-glucuronidase in the colon is able to release carcinogens from hepatic-derived glucuronic acid conjugates and is a critical factor in the enterohepatic circulation of drugs and other foreign compounds. As mentioned by Rafter et al.: 'Although it represents a simple reproducible marker, evidence for a role for $\beta$-glucuronidase in human colorectal cancer is indirect and is remote from the final end-point (tumours), 89

Azo- and nitroreductases reduce their substrates to amines, which are usually more toxic than the parent compound, and nitrate reductase generates the highly reactive and toxic anion, nitrite. ${ }^{90}$ Ammonia is considered to be a potential tumour promoter in the colon, and the hypothesis that it enhances neoplastic transformation in the gut has been advanced. Other gut bacterial products with possible adverse effects on the colonic mucosa include secondary bile acids, which are potential harmful substances. ${ }^{71}$ They may exhibit carcinoge- nicity by acting on the mucous-secreting cells and promoting their proliferation, or they may act as promoters of carcinogenesis. ${ }^{91}$

There is some evidence that selected microorganisms, such as probiotic bifidobacteria, may protect the host from carcinogenic activity by decreasing the production and/or activity of these potential carcinogens. ${ }^{92-94}$ There is experimental date to suggest that probiotic metabolism may indeed beneficially influence faecal enzymes activity. ${ }^{91}$ For example, consumption of milk fermented with a Bifidobacterium species for 12 days decreased $\beta$-glucuronidase activity compared with baseline, even though if it had no effect on faecal $\mathrm{pH}$ or the activity of nitrate reductase, nitroreductase and azoreductase. ${ }^{95}$ In another study, consumption of a fermented milk with L. acidophilus, B. bifidum, Streptococcus lactis and Streptococcus cremoris for 3 weeks decreased the activity of nitroreductase from baseline, even though if it did not modulate the activity of $\beta$-glucuronidase and azoreductase. ${ }^{87}$ In vitro and in vivo in rats, B. animalis DN-173 010 shows $\beta$-fructofuranosidase and $\beta$-galactosidase activities. These activities are enhanced by some prebiotics like transgalactooligosaccharides (C. Andrieux, personal communication). $\beta$-Fructofuranosidase and $\beta$-galactosidase are considered as positive markers of colon health. ${ }^{96}$

\section{Bifidobacteria, nitrosamines, nitrites and heterocyclic amines}

Positive modulation of nitrosamines, nitrites and heterocyclic amines production by bifidobacteria has been reported. ${ }^{97,} 98$ An in vitro study showed that the growth of bifidobacteria strains was not affected by low nitrite concentrations and that acids produced by bifidobacteria seemed to be involved in nitrite elimination. $^{99}$ With regards to heterocyclic amines, anti-mutagenic effects were demonstrated in a study investigating the efficacy of a wide range of LAB against 2-amino-3-methylimidazo[4,5-f]quinoline (IQ) mutagenicity; a significant anti-mutagenic effect was shown with eight Lactobacillus out of 76 LAB. ${ }^{98}$ Other bacteria were studied, using TNO's in vitro large intestine model (TIM-2). In this model, the potential beneficial effect of B. animalis $\mathrm{DN}-173010$ on bioconversion and mutagenicity of heterocyclic amines was confirmed. This finding has been reported at Congrilait in 2002 (K. Venema, personal communication). 


\section{Bifidobacteria and their effects on bile acids}

Many intestinal bacteria, including Bifidobacterium and Lactobacillus species, can deconjugate or hydrolyse conjugated bile acids. ${ }^{100}$ Between-species differences in hydrolase activity has been evidenced. ${ }^{101}$

Although initially considered as useful property, ${ }^{102}$ this activity has since been suggested to constitute a health disadvantage as it may increase the formation of secondary cytotoxic bile acids. ${ }^{100,103}$ However, a recent trial performed in pigs, receiving either living bacteria or killed bacteria for 2 weeks, showed that $B$. animalis DN173010 , which has a bile salt hydrolase activity in vitro, was also active in vivo during its transit through the gastrointestinal tract. Moreover this probiotic strain did not induce cytotoxic bile acids production: unconjugated bile acids levels were significantly lower in the group receiving living bacteria. ${ }^{104,105}$

In man, a randomized double-blind, controlled trial showed that faecal concentrations of total secondary bile acids, deoxycholic acid and lithocholic acid were not significantly different in healthy women consuming a fermented milk procuring $2 \times 10^{10}$ to $4 \times 10^{10} \mathrm{CFU} /$ day of B. animalis DN-173 010. ${ }^{106}$

\section{Effects of bifidobacteria on cell proliferation}

Probiotic-enriched fermented milks may exert beneficial effects on intestinal cell proliferation. Markers such as DNA damage, microadenomas and aberrant crypt foci in the mucosa, can be used to identify early epithelial events linked to colonic cancer. Induction of aberrant crypt foci has been particularly widely used, as it is easily observed macroscopically. In man, aberrant crypts and microadenomas, similar to those described in animals, have been described, ${ }^{107}$ but need to be correlated with other well-known markers of tumour risk.

An in vitro study using IEC-6 cell cultures demonstrated that fermented milks containing probiotic bifidobacteria stimulate mitochondrial deshydrogenase response, DNA synthesis and cyclic AMP production. ${ }^{108}$

In a pathogenic context, in vitro and in vivo studies showed that several LAB present in fermented milks may have an inhibitory effect on the development of precancerous lesions and tumours in animal models. ${ }^{103}$ In Ames' test, B. animalis DN-173 010 has been shown to have an inhibitory effect towards indirect mutagenic agents in vitro. ${ }^{109-111}$ In vivo, in rats, several studies

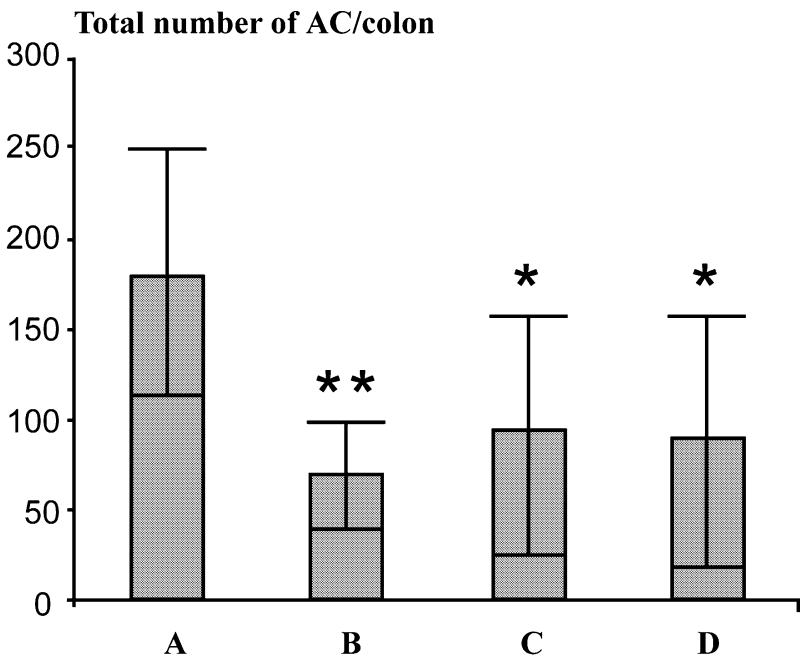

Figure 4. Effect of dairy-supplemented diets on the number of aberrant crypts (AC) in 1,2-dimethylhydrazine-treated rats. A: control diet; B: diet supplemented with DN-173 010 suspension; C: diet supplemented with fermented skim milk by DN-173 010 strain; D; diet supplemented with uninoculated skim milk. Student's $t$-test was used for statistical comparison; ** $P<0.01$; ${ }^{*} P<0.05$. Adapted from Abdelali et al. ${ }^{108}$

have confirmed the protective effects of milk, fermented milk and various LAB with respect to chemicallyinduced colonic carcinogenesis. ${ }^{109,} 112,113$ Using aberrant crypts as an oncogenesis marker, Abdelali et al. reported a $61 \%$ reduction in crypt foci in rats fed a normal diet supplemented with a suspension containing $2.1 \times 10^{10}$ B. animalis DN-173 010 vs. the controls; $\beta$-glucuronidase activity was also significantly decreased. ${ }^{109}$ Figure 4 illustrates these results.

The above studies mainly used 1,2-dimethylhydrazine or azoxymethanol, its metabolite, as carcinogens and aberrant colon crypts as carcinogenesis markers. Using the comet assay, two short-term studies in rats showed that bacteria such as Lactobacillus, Bifidobacterium and $S$. thermophilus were able to decrease colon DNA damage after exposure to the genotoxic agent, 1,2dimethylhydrazine. ${ }^{113,114}$ Using F344 male rats fed a diet supplemented with $B$. longum, the following were demonstrated: (i) a $100 \%$ colonic tumour inhibition ${ }^{115}$; (ii) a significant decrease in the number of azoxymethane-induced colonic aberrant crypt foci and in the total number of aberrant crypts ${ }^{111}$; and (iii) a significant suppression of colon tumour incidence, tumour multiplicity and tumour volume. ${ }^{116}$ The latter study, also evidenced modulation of the intermediate biomarkers of colon carcinogenesis, such as colonic mucosal and/or 
tumour cell proliferation, ornithine decarboxylase activity and ras-p21 oncoprotein expression. ${ }^{116}$ A significant decrease in the faecal bacterial $\beta$-glucuronidase activity was also observed in the animals fed Bifidobacteriumsupplemented diets vs. the control diet. ${ }^{117}$

A further carcinogenesis model (heterocyclic aromatic amines) was used to test the preventive potential of fermented milk containing B. animalis DN-173 010 and $S$. thermophilus DN-001 $158 .{ }^{83}$ The fermented milk significantly reduced the total number of aberrant crypts induced by diet containing heterocyclic aromatic amine carcinogens, but non-fermented milk has almost the same effect. ${ }^{83}$ These results concord with those of a previous study, which showed that skimmed milk alone decreased the incidence and number of aberrant colonic crypt formation in 1,2-dimethylhydrazine treated rats. ${ }^{108}$ In conclusion, the intermediate biomarkers used in the above studies showed that dairy products decreased aberrant colonic crypt formation, which may be operative at the initiation stage of the carcinogenetic process.

Using cultured human colonic cancer cell line HT-29, Baricault et al. studied at the cellular level the effect of fermented milks on colon cancer cell growth and differentiation characteristics ${ }^{118}$; Bifidobacterium was among the most effective bacterial species that lowered the HT-29 growth rate. Concomitantly, the specific activities of dipeptidyl peptidase IV, a sensitive and specific marker of HT-29 cell differentiation, and that of three other brush border enzymes (sucrase, aminopeptidase $\mathrm{N}$ and alkaline phosphatase) were significantly increased, thus suggesting that the cells may have entered a differentiation process. ${ }^{118}$

Overall, these results suggest that probiotic-containing dairy products could help to prevent colonic carcinogenesis. Obviously, more extensive investigations and clinical trials must be conducted on this ongoing topic.

\section{CONCLUSIONS}

Bifidobacteria, as probiotics, may become an important means of enhancing digestive health and preventing disease. In order to realize this potential fully, research must focus on the following areas: (i) identification of Bifidobacterium strains that can withstand gastrointestinal transit (i.e. gastric acidity, bile salts and Paneth cell secretions); (ii) identification of the Bifidobacterium species and strains that are effective against specific disease processes or in disease prevention; (iii) investigation of the mechanisms of probiotic action; and (iv) development of new association between bifidobacteria strains and prebiotics. Currently, the utilization of probiotics and prebiotics is an interesting field of research as several probiotic strains, including B. animalis DN-173 010, show a more preferential fermentation pattern when associated with short-chain oligomers than with monomers. ${ }^{119-121}$ A recent study $^{79}$ has shown a beneficial effect of a prebiotic and probiotic association highlighting the growing interest of synbiotics in digestive health.

\section{REFERENCES}

1 Guarner F, Malagelada JR. Gut flora in health and disease. Lancet 2003; 361: 512-9.

2 Suau A, Bonnet R, Sutren M, et al. Direct analysis of genes encoding 16S rRNA from complex communities reveals many novel molecular species within the human gut. Appl Environ Microbiol 1999; 65: 4799-807.

3 Blaut M, Collins MD, Welling GW, Dore J, van Loo J, de Vos W. Molecular biological methods for studying the gut microbiota: the EU human gut flora project. Br J Nutr 2002; 87(Suppl. 2): S203-11.

4 Marteau P, Pochart P, Dore J, Bera-Maillet C, Bernalier A, Corthier G. Comparative study of bacterial groups within the human cecal and fecal microbiota. Appl Environ Microbiol 2001; 67: 4939-42.

5 Matsuki T, Watanabe K, Fujimoto J, et al. Quantitative PCR with 16S rRNA-gene-targeted species-specific primers for analysis of human intestinal bifidobacteria. Appl Environ Microbiol 2004a; 70: 167-73.

6 Matsuki T, Watanabe K, Fujimoto J, Takada T, Tanaka R. Use of 16S rRNA Gene-Targeted Group-Specific Primers for Real-Time PCR Analysis of Predominant Bacteria in Human Feces. Appl Environ Microbiol 2004b; 70: 7220-8.

7 Salminen S, Bouley C, Boutron-Ruault M-C, et al. Functional food science and gastrointestinal physiology and function. British Journal of Nutrition 1998; 80(Suppl. 1): S147-71.

8 Yoshioka H, Isaki K, Fujita K. Development and differences of intestinal flora in the neonatal period in breast-fed and bottlefed infants. Pediatrics 1983; 72: 317-21.

9 Harmsen HJ, Wildeboer-Veloo AC, Raangs GC, et al. Analysis of intestinal flora development in breast-fed and formula-fed infants by using molecular identification and detection methods. J Pediatr Gastroenterol Nutr 2000; 30: 61-7.

10 Cummings JH, Macfarlane GT. Gastrointestinal effects of prebiotics. Br J Nutr 2002; 87(Suppl. 2): S145-51.

11 Bouhnik Y, Raskine L, Simoneau G, et al. The capacity of nondigestible carbohydrates to stimulate fecal bifidobacteria in healthy humans: a double-blind, randomized, placebocontrolled, parallel-group, dose-response relation study. Am J Clin Nutr 2004; 80: 1658-64.

12 Adams MR, Marteau P. On the safety of lactic acid bacteria from food (Letter to the editor). Intl J Fd Microbiol 1995; 27: 263-4. 
13 Ishibashi N, Yamazaki S. Probiotics and safety. Am J Clin Nutr 2001; 73: 465S-70S.

14 Makelainen H, Tahvonen R, Salminen S, Ouwehand AC. In vivo safety assessment of two Bifidobacterium longum strains. Microbiol Immunol 2003; 47: 911-4.

15 Borriello SP, Hammes WP, Holzapfel W, et al. Safety of probiotics that contain lactobacilli or bifidobacteria. Clin Infect Dis 2003; 36: 775-80.

16 Holzapfel WH, Haberer P, Geisen R, Bjorkroth J, Schillinger U. Taxonomy and important features of probiotic microorganisms in food and nutrition. Am J Clin Nutr 2001; 73: 365S-73S.

17 Miyake T, Watanabe K, Watanabe T, Oyaizu H. Phylogenetic analysis of the genus Bifidobacterium and related genera based on $16 \mathrm{~S}$ rDNA sequences. Microbiol Immunol 1998; 42: 661-7.

18 European commission (Health and Consumer protection directorate-general). Qualified Presumption of Safety. On a Generic Approach to the Safety Assessment of micro-organisms Used in Feed/food and Feed/food Production. http:// www.efsa.eu.int/science/colloquium_series/no2_qps/610/ colloq02_sanco_discuss_en1.pdf.

19 FAO/WHO. Report of a Joint FAO/WHO Expert Group. Health and Nutritional Properties of Probiotics in Food Including Powder milk with Live Lactic Acid Bacteria. Cordoba, Argentina: Food and Agricultural Organization of the United Nations, World Health Organization, 1-4 October 2001, http://www.who.int/foodsafety/publications/fs_management/ en/probiotics.pdf.

20 Gibson GR, Roberfroid MB. Dietary modulation of the human colonic microbiota: introducing the concept of prebiotics. J Nutr 1995; 125: 1401-12.

21 Pochart P, Marteau P, Bouhnik Y, Goderel I, Bourlioux P, Rombard JC. Survival of bifidobacteria ingested via fermented milk during their passage through the human small intestine: an in vivo study using intestinal perfusion. Am J Clin Nutr 1992; 55: 78-80.

22 Bouhnik Y, Pochart P, Marteau P, Arlet G, Goderel I, Rambaud JC. Fecal recovery in humans of viable Bifidobacterium sp. ingested in fermented milk. Gastroenterology 1992; 102: 875-8.

23 Berrada N, Lelemand JF, Laroche G, Thouvenot P, Piaia M. Bifidobacterium from fermented milks: survival during gastric transit. J Dairy Sci 1991; 74: 409-13.

24 Bezkorovainy A. Probiotics: determinants of survival and growth in the gut. Am J Clin Nutr 2001; 73: 399S-405S.

25 Pochart P, Marteau P, Bissetti N, Goderel I, Bourlioux P, Rombard J. Isolement des bifidobactéries dans les selles après ingestion prolongée de lait au bifidus (LB). Méd Mal Infect 1990; 75-8 (special issue).

26 Duez H, Pelletier C, Cools S, et al. A colony immunoblotting method for quantitative detection of a Bifidobacterium animalis probiotic strain in human faeces. Journal of Applied Microbiology 2000; 88: 1019-27.

27 Marteau P, Pochart P, Bouhnik Y, Zidi S, Goderel I, Rambaud JC. Survival of Lactobacillus acidophilus and Bifidobacterium sp. in the small intestine following ingestion in fermented milk.
A rational basis for the use of probiotics in man. Gastroenterol Clin Biol 1992; 16: 25-28.

28 Kullen MJ, Amann MM, O'Shaughnessy MJ, O'Sullivan DJ, Busta FF, Brady LJ. Differentiation of ingested and endogenous bifidobacteria by DNA fingerprinting demonstrates the survival of an unmodified strain in the gastrointestinal tract of humans. J Nutr 1997; 127: 89-94.

29 Marteau PR. Probiotics in clinical conditions. Clin Rev Allergy Immunol 2002; 22: 255-73.

30 Bouvier M, Meance S, Bouley C, Berta JL, Grimaud JC. Effects of consumption of a milk fermented by the probiotic strain Bifidobacterium animalis DN-173 010 on colonic transit times in healthy humans. Bioscience Microflora 2001; 20: 43-48.

31 Marteau P, Cuillerier E, Meance S, et al. Bifidobacterium animalis strain DN-173 010 shortens the colonic transit time in healthy women: a double- blind, randomized, controlled study. Aliment Pharmacol Th 2002; 16: 587-93.

32 Meance S, Cayuela C, Raimondi A, Turchet P, Lucas C, Antoine JM. Recent advances in the use of functional foods: effects of the commercial fermented milk with Bifidobacterium animalis strain DN-173 010 and yoghurt strains on gut transit time in the elderly. Microbial Ecology in Health and Disease 2003; 15: 15-22.

33 Meance S, Cayuela C, Turchet P, Raimondi A, Lucas C, Antoine JM. A fermented milk with a bifidobacterium probiotic strain DN-173 010 shortened oro-fecal gut transit time in elderly. Microbial Ecology in Health and Disease 2001; 13: 217-22.

34 Mortensen PB, Clausen MR. Short-chain fatty acids in the human colon: relation to gastrointestinal health and disease. Scand J Gastroenterol Suppl 1996; 216: 132-48.

35 Bugaut M, Bentejac M. Biological effects of short-chain fatty acids in nonruminant mammals. Annu Rev Nutr 1993; 13: 217-41.

36 Boffa LC, Lupton JR, Mariani MR, et al. Modulation of colonic epithelial cell proliferation, histone acetylation, and luminal short chain fatty acids by variation of dietary fiber (wheat bran) in rats. Cancer Res 1992; 52: 5906-12.

37 Cummings JH. Short chain fatty acids. In: Gibson GR, Macfarlane GT, eds. Human Colonic Bacteria: Role in Nutrition, Physiology and Pathology. CRC Press: Boca Raton, 1995: 101-30.

38 Duncan SH, Louis P, Flint HJ. Lactate-utilizing bacteria, isolated from human feces, that produce butyrate as a major fermentation product. Appl Environ Microbiol 2004; 70: 5810-7.

39 Crittenden RG, Martinez NR, Playne MJ. Synthesis and utilisation of folate by yoghurt starter cultures and probiotic bacteria. Int J Food Microbiol 2003; 80: 217-22.

40 Krause LJ, Forsberg CW, O'Connor DL. Feeding human milk to rats increases Bifidobacterium in the cecum and colon which correlates with enhanced folate status. J Nutr 1996; 126: 1505-11.

41 Lievin V, Peiffer I, Hudault S, et al. Bifidobacterium strains from resident infant human gastrointestinal microflora exert antimicrobial activity. Gut 2000; 47: 646-52. 
42 Gibson GR, Wang X. Regulatory effects of bifidobacteria on the growth of other colonic bacteria. J Appl Bacteriol 1994; 77: 412-20.

43 Fujiwara S, Hashiba H, Hirota T, Forstner JF. Proteinaceous factor(s) in culture supernatant fluids of bifidobacteria which prevents the binding of enterotoxigenic Escherichia coli to gangliotetraosylceramide. Appl Environ Microbiol 1997; 63: 506-12.

44 Perdigon G, Alvarez S, Rachid M, Aguero G, Gobbato N. Immune system stimulation by probiotics. J Dairy Sci 1995; 78: 1597-606.

45 Duffy LC, Zielezny MA, Riepenhoff-Talty M, et al. Reduction of virus shedding by $B$. bifidum in experimentally induced MRV infection. Statistical application for ELISA. Dig Dis Sci 1994; 39: 2334-40.

46 Duffy LC, Zielezny MA, Riepenhoff-Talty M, et al. Effectiveness of Bifidobacterium bifidum in mediating the clinical course of murine rotavirus diarrhea. Pediatr Res 1994; 35: 690-5.

47 Yamazaki S, Tsuyuki S, Akashiba H, et al. Immune response of Bifidobacterium-monoassociated mice. Bifidobacterio Microflora 1991; 10: 19-31.

48 Yamazaki S, Machii K, Tsuyuki S, Momose H, Kawashima T, Ueda K. Immunological responses to monoassociated Bifidobacterium longum and their relation to prevention of bacterial invasion. Immunology 1985; 56: 43-50.

49 Tomoda T, Nakano Y, Kageyama T. Intestinal Candida overgrowth and Candida infection in patients with leukemia: effect of Bifidobacterium administration. Bifidobacteria Microflora 1998; 7: 71-74.

50 Yasui H, Kiyoshima J, Ushijima H. Passive protection against rotavirus-induced diarrhea of mouse pups born to and nursed by dams fed Bifidobacterium breve YIT4064. J Infect Dis 1995; 172: 403-9.

51 Brandtzaeg P, Halstensen TS, Kett K, et al. Immunobiology and immunopathology of human gut mucosa: humoral immunity and intraepithelial lymphocytes. Gastroenterology 1989; 97: 1562-84.

52 Brandtzaeg P. Molecular and cellular aspects of the secretory immunoglobulin system. Apmis 1995; 103: 1-19.

53 Sanderson IR, Walker WA. Uptake and transport of macromolecules by the intestine: possible role in clinical disorders (an update). Gastroenterology 1993; 104: 62239.

54 Ouwehand A, Isolauri E, Salminen S. The role of the intestinal microflora for the development of the immune system in early childhood. Eur J Nutr 2002; 41(Suppl. 1): I32-7.

55 Gill HS. Probiotics to enhance anti-infective defences in the gastrointestinal tract. Best Pract Res Clin Gastroenterol 2003; $17: 755-73$.

56 Schiffrin EJ, Rochat F, Link-Amster H, Aeschlimann JM, Donnet-Hughes A. Immunomodulation of human blood cells following the ingestion of lactic acid bacteria. J Dairy Sci 1995; 78: 491-7.

57 Schiffrin EJ, Brassart D, Servin AL, Rochat F, Donnet-Hughes A. Immune modulation of blood leukocytes in humans by lactic acid bacteria: criteria for strain selection. Am J Clin Nutr 1997; 66: 515S-20S.

58 De Simone C, Ciardi A, Grassi A, et al. Effect of Bifidobacterium bifidum and Lactobacillus acidophilus on gut mucosa and peripheral blood B lymphocytes. Immunopharmacol Immunotoxicol 1992; 14: 331-40.

59 de Roos NM, Katan MB. Effects of probiotic bacteria on diarrhea, lipid metabolism, and carcinogenesis: a review of papers published between 1988 and 1998. Am J Clin Nutr 2000; 71: 405-11.

60 Moreau MC, Bisetti N, Dubuquoy C. Immunomodulating properties of a strain of Bifidobacterium used as probiotic on the fecal and cellular intestinal IgA antirotavirus responses in mice. In: Fondation BN, ed. Functional Foods: The Consumer, the Products and the Evidence. Cambridge: The Royal Society of Chemistry, 1998: 47-51.

61 Moreau MC, Gaboriau-Routhiau V, Dubuquoy C, Bisetti N, Bouley C, Prevoteau H. Modulating properties of intestinal bacterial strains, Escherichia coli and Bifidobacterium, on two specific immune responses generated by the gut, i.e oral tolerance to ovalbumine and intestinal IgA anti-rotavirus response, in gnotobiotic mice. In: Talwar G, Nath I, Ganguly $\mathrm{N}$, Rao K, eds. International Congress of Immunology. New Delhi, India: Monduzzi, 1998: 407-11.

62 Saavedra JM, Bauman NA, Oung I, Perman JA, Yolken RH. Feeding of Bifidobacterium bifidum and Streptococcus thermophilus to infants in hospital for prevention of diarrhoea and shedding of rotavirus. Lancet 1994; 344: 1046-9.

63 Phuapradit P, Varavithya W, Vathanophas K, et al. Reduction of rotavirus infection in children receiving bifidobacteria-supplemented formula. J Med Assoc Thai 1999; 82(Suppl. 1): S43-8.

64 Chouraqui JP, Van Egroo LD, Fichot MC. Acidified milk formula supplemented with Bifidobacterium lactis: impact on infant diarrhea in residential care settings. J Pediatr Gastroenterol Nutr 2004; 3: 288-92.

65 Chouraqui JP, Van Egroo LD, Fichot MC. Acidified milk formula supplemented with Bifidobacterium lactis: impact on infant diarrhea in residential care settings. J Pediatr Gastroenterol Nutr 2004; 38: 288-92.

66 Bhatia SJ, Kochar N, Abraham P, Nair NG, Mehta AP. Lactobacillus acidophilus inhibits growth of Campylobacter pylori in vitro. J Clin Microbiol 1989; 27: 2328-30.

67 Jack RW, Tagg JR, Ray B. Bacteriocins of gram-positive bacteria. Microbiol Rev 1995; 59: 171-200.

68 Cremonini F, Di Caro S, Santarelli L, et al. Probiotics in antibiotic-associated diarrhoea. Dig Liver Dis 2002; 34(Suppl. 2): S78-80.

69 Orrhage K, Sjostedt S, Nord CE. Effect of supplements with lactic acid bacteria and oligofructose on the intestinal microflora during administration of cefpodoxime proxetil. J Antimicrob Chemother 2000; 46: 603-12.

70 Plummer S, Weaver MA, Harris JC, Dee P, Hunter J. Clostridium difficile pilot study: effects of probiotic supplementation on the incidence of $C$. difficile diarrhoea. Int Microbiol 2004; 7: 59-62. 
71 Kruis W. Review article: antibiotics and probiotics in inflammatory bowel disease. Aliment Pharmacol Ther 2004; 20(Suppl. 4): 75-78.

72 Sartor RB. Therapeutic manipulation of the enteric microflora in inflammatory bowel diseases: antibiotics, probiotics, and prebiotics. Gastroenterology 2004; 126: 1620-33.

73 Gionchetti P, Rizzello F, Venturi A, et al. Oral bacteriotherapy as maintenance treatment in patients with chronic pouchitis: a double-blind, placebo-controlled trial. Gastroenterology 2000; 119: 305-309.

74 Mimura T, Rizzello F, Helwig U, et al. Once daily high dose probiotic therapy (VSL 3) for maintaining remission in recurrent or refractory pouchitis. Gut 2004; 53: 108-14.

75 Gionchetti P, Rizzello F, Helwig U, et al. Prophylaxis of pouchitis onset with probiotic therapy: a double-blind, placebo-controlled trial. Gastroenterology 2003; 124: 1202-9.

76 Laake KO, Bjorneklett A, Aamodt G, et al. Outcome of four weeks' intervention with probiotics on symptoms and endoscopic appearance after surgical reconstruction with a J-configurated ileal-pouch-anal-anastomosis in ulcerative colitis. Scand J Gastroenterol 2005; 40: 43-51.

77 Ishikawa H, Akedo I, Umesaki Y, Tanaka R, Imaoka A, Otani T. Randomized controlled trial of the effect of bifidobacteriafermented milk on ulcerative colitis. J Am Coll Nutr 2003; 22: 56-63.

78 Kato K, Mizuno S, Umesaki Y, et al. Randomized placebocontrolled trial assessing the effect of bifidobacteriafermented milk on active ulcerative colitis. Aliment Pharmacol Ther 2004; 20: 1133-41.

79 Furrie E, Macfarlane S, Kennedy A, et al. Synbiotic therapy (Bifidobacterium longum/Synergy 1) initiates resolution of inflammation in patients with active ulcerative colitis: a randomised controlled pilot trial. Gut 2005; 54: 242-249.

80 Hamilton-Miller JM. Probiotics in the management of irritable bowel syndrome: a review of clinical trials. Microb Ecol Health Dis 2001; 13: 212-6.

81 O'Mahony L, McCarthy J, Kelly P, et al. Lactobacillus and Bifidobacterium in irritable bowel syndrome: symptom responses and relationship to cytokine profiles. Gastroenterology 2005; 128: 541-51.

82 Trichopoulos D, Li FP, Hunter DJ. What causes cancer? Sci Am 1996; 275: 80-7.

83 Tavan E, Cayuela C, Antoine JM, Trugnan G, Chaugier C, Cassand P. Effects of dairy products on heterocyclic aromatic amine-induced rat colon carcinogenesis. Carcinogenesis 2002; 23: 477-83.

84 Goldin BR, Swenson L, Dwyer J, Sexton M, Gorbach SL. Effect of diet and Lactobacillus acidophilus supplements on human fecal bacterial enzymes. J Natl Cancer Inst 1980; 64: 255-61.

85 Goldin BR. Intestinal microflora: metabolism of drugs and carcinogens. Ann Med 1990; 22: 43-8.

86 Ling WH, Korpela R, Mykkanen H, Salminen S, Hanninen O. Lactobacillus strain GG supplementation decreases colonic hydrolytic and reductive enzyme activities in healthy female adults. J Nutr 1994; 124: 18-23.
87 Marteau P, Pochart P, Flourie B, et al. Effect of chronic ingestion of a fermented dairy product containing Lactobacillus acidophilus and Bifidobacterium bifidum on metabolic activities of the colonic flora in humans. Am J Clin Nutr 1990; 52: 685-8.

88 Pedrosa MC, Golner BB, Goldin BR, Barakat S, Dallal GE, Russell RM. Survival of yogurt-containing organisms and Lactobacillus gasseri (ADH) and their effect on bacterial enzyme activity in the gastrointestinal tract of healthy and hypochlorhydric elderly subjects. Am J Clin Nutr 1995; 61: 353-9.

89 Rafter J, Govers M, Martel P, et al. PASSCLAIM - diet-related cancer. Eur J Nutr 2004; 43(Suppl. 2): II47-84.

90 Walker R. Nitrates, nitrites and N-nitrosocompounds: a review of the occurrence in food and diet and the toxicological implications. Food Addit Contam 1990; 7: 717-68.

91 Cheah PY. Hypotheses for the etiology of colorectal cancer an overview. Nutr Cancer 1990; 14: 5-13.

92 Rowland IR, Grasso P. Degradation of N-nitrosamines by intestinal bacteria. Appl Microbiol 1975; 29: 7-12.

93 Orrhage K, Sillerstrom E, Gustafsson JA, Nord CE, Rafter J. Binding of mutagenic heterocyclic amines by intestinal and lactic acid bacteria. Mutat Res 1994; 311: 239-48.

94 Saikali J, Picard C, Freitas M, Holt P. Fermented milks, probiotic cultures, and colon cancer. Nutr Cancer 2004; 49: $14-24$.

95 Bouhnik Y, Flourie B, Andrieux C, Bisetti N, Briet F, Rambaud JC. Effects of Bifidobacterium sp fermented milk ingested with or without inulin on colonic bifidobacteria and enzymatic activities in healthy humans. Eur J Clin Nutr 1996; 50: 269-73.

96 Andrieux CM, Cayuela C, Antoine JM. Metabolic characteristics of the faecal microflora in humans from three age groups. Scand J Gastroenterol 2002; 37: 792-8.

97 Ayanaba A, Alexander M. Microbial formation of nitrosamines in vitro. Appl Microbiol 1973; 25: 862-8.

98 Tavan E, Cayuela C, Antoine JM, Cassand P. Antimutagenic activities of various lactic acid bacteria against food mutagens: heterocyclic amines. Journal of Dairy Research 2002; 69: 335-41.

99 Grill JP, Crociani J, Ballongue J. Effect of bifidobacteria on nitrites and nitrosamines. Lett Appl Microbiol 1995; 20: 328-30.

100 Midtvedt T, Norman A. Bile acid transformations by microbial strains belonging to genera found in intestinal contents. Acta Pathol Microbiol Scand 1967; 71: 629-38.

101 Grill JP, Manginot-Durr C, Schneider F, Ballongue J. Bifidobacteria and probiotic effects: action of Bifidobacterium species on conjugated bile salts. Curr Microbiol 1995; 31 : $23-7$.

102 Tanaka H, Doesburg K, Iwasaki T, Mierau I. Screening of lactic acid bacteria for bile salt hydrolase activity. J Dairy Sci 1999; 82: 2530-5.

103 Brady LJ, Gallaher DD, Busta FF. The role of probiotic cultures in the prevention of colon cancer. J Nutr 2000; 130: 410S-4S. 
104 Lepercq P. Increasing Ursodeoxycholic acid in the enterohepatic circulation of pigs through the administration of living bacteria. Br J Nutr 2005; 93: 457-9.

105 Lepercq P. Bifidobacterium animalis strain DN-173 010 hydrolyses bile salts in the gastrointestinal tract of pigs. Scand J Gastroenterol 2004; 39: 1266-71.

106 Roncucci L. Early events in human colorectal carcinogenesis. Aberrant crypts and microadenoma. Ital J Gastroenterol 1992; 24: 498-501.

107 Thoreux K, Senegas BF, Bernard PF, et al. Modulation of proliferation, second messenger levels, and morphotype expression of the rat intestinal epithelial cell line IEC-6 by fermented milk. J. Dairy Sci 1996; 79: 33-43.

108 Abdelali H, Cassand P, Soussotte V, Daubeze M, Bouley C, Narbonne JF. Effect of dairy products on initiation of precursor lesions of colon cancer in rats. Nutr Cancer 1995; 24: 121-32.

109 Abdelali H, Cassand P, Soussotte V, Koch-Bocabeille B, Narbonne JF. Antimutagenicity of components of dairy products. Mutat Res 1995; 331: 133-41.

110 Cassand P, Abdelali H, Bouley C, Denariaz G, Narbonne JF. Inhibitory effect of dairy products on the mutagenicities of chemicals and dietary mutagens. J Dairy Res 1994; 61: 545-52.

111 Challa A, Rao DR, Chawan CB, Shackelford L. Bifidobacterium longum and lactulose suppress azoxymethane-induced colonic aberrant crypt foci in rats. Carcinogenesis 1997; 18: 517-21.

112 Gallaher DD, Stallings WH, Blessing LL, Busta FF, Brady LJ. Probiotics, cecal microflora, and aberrant crypts in the rat colon. J Nutr 1996; 126: 1362-71.

113 Pool-Zobel BL, Neudecker C, Domizlaff I, et al. Lactobacillusand Bifidobacterium-mediated antigenotoxicity in the colon of rats. Nutr Cancer 1996; 26: 365-80.
114 Wollowski I, Ji ST, Bakalinsky AT, Neudecker C, Pool-Zobel BL. Bacteria used for the production of yogurt inactivate carcinogens and prevent DNA damage in the colon of rats. J Nutr 1999; 129: 77-82.

115 Reddy BS, Rivenson A. Inhibitory effect of Bifidobacterium longum on colon, mammary, and liver carcinogenesis induced by 2-amino-3-methylimidazo[4,5-f]quinoline, a food mutagen. Cancer Res 1993; 53: 3914-8.

116 Singh J, Rivenson A, Tomita M, Shimamura S, Ishibashi N, Reddy BS. Bifidobacterium longum, a lactic acid-producing intestinal bacterium inhibits colon cancer and modulates the intermediate biomarkers of colon carcinogenesis. Carcinogenesis 1997; 18: 833-41.

117 Kulkarni N, Reddy BS. Inhibitory effect of Bifidobacterium longum cultures on the azoxymethane-induced aberrant crypt foci formation and fecal bacterial beta-glucuronidase. Proc Soc Exp Biol Med 1994; 207: 278-83.

118 Baricault L, Denariaz G, Houri JJ, Bouley C, Sapin C, Trugnan G. Use of HT-29, a cultured human colon cancer cell line, to study the effect of fermented milks on colon cancer cell growth and differentiation. Carcinogenesis 1995; 16: 245-52.

119 Jian W. New approach to phylogenic analysis of the genus Bifidobacterium based on partial HSP60 gene sequences. Int J Syst Evol Microbiol 2001; 51: 1633-8.

120 Roller M, Femia AP, Caderni G, Rechkemmer G, Watzl B. Intestinal immunity of rats with colon cancer is modulated by oligofructose-enriched inulin combined with Lactobacillus rhamnosus and Bifidobacterium lactis. Br J Nutr 2004; 92: 931-8.

121 Van der Meulin R, Avonts L, De Vuyst L. Short fractions of oligofructose are preferentially metabolized by Bifidobacterium animalis DN-173 010. App Environ Microbiol 2004; 70: 1923-30. 